\title{
Effect of Organic Input Application on Soil Microbial and Biochemical Properties on Gladiolus (Gladiolus grandiflorus L.) under Jorhat Condition
}

\author{
Dipanjali Baruati ${ }^{1 *}$, Madhumita Choudhury Talukdar ${ }^{1}$, \\ Dhrubajyoti Nath $^{1}$ and Tara Bhuyan ${ }^{2}$
}
${ }^{I}$ Department of Horticulture, Assam Agricultural University, Jorhat-785 013 (Assam), India
${ }^{2}$ Department of Agriculture, Arunachal University of Studies, Namsai, Arunachal Pradesh, India

*Corresponding author

\begin{abstract}
A B S T R A C T
Soil enzymes, microbial biomass carbon (MBC), soil microbial population and soil biochemical properties were assessed to understand the influence of different organic

Keywords

Enzymes, Gladiolus,

Enriched compost,

Vermicompost,

Microbial, Consortium,

Nitrogen

Article Info

Accepted:

12 September 2018

Available Online:

10 October 2018

inputs on gladiolus under open condition during 2015-16 to 2016-17. The experiment was laid out with 8 treatments in Randomized Block Design and replicated 3 times. The treatments were $\mathrm{T}_{1}\left[\mathrm{RDF}\left(20: 20: 20 \mathrm{~g} \mathrm{~m}^{-2} \mathrm{NPK}+4 \mathrm{~kg} \mathrm{~m}^{-2} \mathrm{FYM}\right)\right], \mathrm{T}_{2}$ [Rock phosphate + Microbial consortium], $\mathrm{T}_{3}\left[\mathrm{~T}_{2}+\right.$ Vermicompost $\left.\left(2.5 \mathrm{t} \mathrm{ha}^{-1}\right)\right], \mathrm{T}_{4}\left[\mathrm{~T}_{2}+\right.$ Vermicompost (5 t $\left.\left.\mathrm{ha}^{-1}\right)\right], \mathrm{T}_{5}\left[\mathrm{~T}_{2}+\right.$ Compost $\left.\left(2.5 \mathrm{t} \mathrm{ha}^{-1}\right)\right], \mathrm{T}_{6}\left[\mathrm{~T}_{2}+\right.$ Compost $\left.\left(5 \mathrm{t} \mathrm{ha}^{-1}\right)\right], \mathrm{T}_{7}$ [Enriched compost $\left.\left(2.5 \mathrm{t} \mathrm{ha}^{-1}\right)\right]$ and $\mathrm{T}_{8}$ [Enriched compost $\left.\left(5 \mathrm{t} \mathrm{ha}^{-1}\right)\right]$. The soil enzymes fluorescein di-acetate (FDA), phosphomonoesterase (PMEase), dehydrogenase (DH), arylesterase (ARE) and arylsulphatase (ARS) involved in energy flow and nutrient cycling showed significant higher activities under different organic inputs. $\mathrm{T}_{8}$ (Enriched compost $5 \mathrm{t} \mathrm{ha}^{-1}$ ) demonstrated clear increase in FDA $\left(8.35 \mu \mathrm{g}\right.$ fluorescein $\mathrm{g}^{-1}$ soil $\left.^{-1}\right)$, PMEase $(63.76 \mu \mathrm{g} p$ nitrophenol $\mathrm{g}^{-1}$ soil h$\left.^{-1}\right)$, DH (125.42 $\mu \mathrm{g}$ TPF $\mathrm{g}^{-1}$ soil $\left.24 \mathrm{~h}^{-1}\right)$, ARS $(20.79 \mu \mathrm{g} p$-nitrophenol $\mathrm{g}^{-1}$ soil $\left.\mathrm{h}^{-1}\right)$, ARE (147.97 $\mu \mathrm{g} p$-nitrophenol $\mathrm{g}^{-1}$ soil h$\left.^{-1}\right), \operatorname{MBC}\left(522.90 \mu \mathrm{g} \mathrm{g}^{-1}\right.$ soil) and microbial population in gladiolus. Maximum organic carbon (1.12\%) accumulation was observed in treatment $\mathrm{T}_{8}$.
\end{abstract}

\section{Introduction}

Gladiolus (Gladiolus grandiflorus L.) belongs to the family Iridaceae and native to Europe, Mediterrenean region and South Africa. It is also known as queen of bulbous ornamental plants and sword lily. It has fascinating spikes that contains attractive, elegant, dazzling and delicate florets that open in sequence over longer duration and hence having good keeping quality for cut spikes. It is mainly used for garden, interior decoration and for making bouquets. It is available in various range of colour from blackish to white, pink, violet, lilace or mauve, greenish, smoky and combinations of these colours are also available (Singh et al., 2014).

Gladiolus has a high nutrient requirement and hence proper fertilization is essential for its cultivation. The continuous and unbalanced use of conventional fertilizers leads to 
decreased nutrient uptake efficiency of plants resulting in decreased crop yield. It also causes serious threat to soil health. Steady decline in soil organic matter levels due to continuous cropping with injudicious applications of chemical fertilizers has led to negative nutrient balances in Indian agriculture, impaired soil health and weaken factor productivity (Rao, 2007). Recent studies have focused on traditional fertilization practices to enhance soil organic input by amendments of crop residues, green manure, and farmyard manure.

To boost up the yield potential use of organic manure and bio-agents plays an important role in enhancing its flowering and corm yield. As reported in numerous studies, Azosprillum and Azotobacter are well known symbiotic Nfixing bacteria which help the plants indirectly through better nitrogen fixation or improving the nutrient availability in the soil. Biofertilizers also control and suppress soil borne diseases and some of inoculants produce antibiotics (Aldrich and Baker, 1970). Organic farming is a production system which avoids or largely excludes the use of synthetically produced fertilizers, pesticides, growth regulators and livestock feed additives. Organic farming methods combine scientific knowledge of ecology and modern technology with traditional farming practices based on naturally occurring biological processes

\section{Materials and Methods}

The present experiment was conducted in the Experimental Farm, Department of Horticulture, Assam Agricultural University, Jorhat-13 during 2015-16 and 2016-17. The experiment was laid out with 8 treatments in Randomized Block Design and replicated 3 times. The treatments were $\mathrm{T}_{1}$ [RDF(20:20:20 $\left.\left.\mathrm{g} \mathrm{m}^{-2} \mathrm{NPK}+4 \mathrm{~kg} \mathrm{~m}^{-2} \mathrm{FYM}\right)\right]$, $\mathrm{T}_{2}$ [Rock phosphate + Microbial consortium], $\mathrm{T}_{3}\left[\mathrm{~T}_{2}+\right.$ Vermicompost $\left.\left(2.5 \mathrm{tha}^{-1}\right)\right], \mathrm{T}_{4}\left[\mathrm{~T}_{2}+\right.$
Vermicompost $\left.\left(5 \mathrm{t} \mathrm{ha}^{-1}\right)\right], \mathrm{T}_{5}\left[\mathrm{~T}_{2}+\right.$ Compost $\left.\left(2.5 \mathrm{t} \mathrm{ha}^{-1}\right)\right], \mathrm{T}_{6}\left[\mathrm{~T}_{2}+\operatorname{Compost}\left(5 \mathrm{t} \mathrm{ha}^{-1}\right)\right], \mathrm{T}_{7}$ [Enriched compost $\left(2.5 \mathrm{t} \mathrm{ha}^{-1}\right)$ ] and $\mathrm{T}_{8}$ [Enriched compost $\left(5 \mathrm{t} \mathrm{ha}^{-1}\right)$ ] to study the effect of organic input application on soil microbial and biochemical properties on gladiolus

\section{Results and Discussion}

The present research work was carried out to study the effect of organic inputs on soil microbial and biochemical properties on gladiolus. The results obtained from the present investigation as well as relevant discussion have been summarized below:

\section{Effect of organics on soil biological properties}

\section{Soil microbial biomass carbon, $\mathrm{MBC}\left(\mu \mathrm{g} \mathrm{g}^{-1}\right.$ soil 24 hour $^{-1}$ )}

Data presented in Table 1, shows significant variation in MBC. The highest MBC (522.90 $\mu \mathrm{g} \mathrm{g}^{-1}$ soil 24 hour $^{-1}$ ) was recorded in the application of $\mathrm{T}_{8}$ (Enriched compost $5 \mathrm{t} \mathrm{ha}^{-1}$ ). This may be due to the application of organic source of nutrients which improves the microbial and enzymatic activities in soil (Rajkonwar, 2012).

\section{Dehydrogenase (DH) activity ( $\mu \mathrm{g}$ TPF $\mathrm{g}^{-1}$ soil 24 hour $^{-1}$ )}

The data in Table 1, shows that the activity of DH enzyme in soil increased significantly due to application of organic sources. The DH activity was higher in $\mathrm{T}_{8}\left(125.42 \mu \mathrm{g} \mathrm{TPF} \mathrm{g}^{-1}\right.$ soil 24 hour $\left.^{-1}\right)$. The effect of higher microbial activity and $\mathrm{MBC}$ resulted in higher $\mathrm{DH}$ activity. The DH plays an important role in the initial stages of the oxidation of soil organic matter and is one of the reliable criteria that signify microbial activity in a given situation. The enzyme is considered to exist as an 
integral part of intact cell but does not accumulate extracellularly in soil.

The application of organic minerals which contains crop residues, animal faeces and their compost etc. to soil usually increases the soil biomass and DH activities (Subhani et al., 2001).

Phosphomonoesterase (PMEase) activity ( $\mu$ g p-nitrophenol $\mathrm{g}^{-1}$ soil hour ${ }^{-1}$ )

From the Table 1, it is observed that highest PMEase activity of $63.76 \mu \mathrm{g}$ p-nitrophenol $\mathrm{g}^{-1}$ soil hour ${ }^{-1}$ under the soil treated with treatment $\mathrm{T}_{8}$ (Enriched compost $5 \mathrm{t} \mathrm{ha}^{-1}$ ). Rock phosphate carrying enriched compost could have augmented the available phosphate in the treatment. It may be due to the release of more organically bound phosphate as a result of synthesis of enzyme which is stimulated by the presence of organic substrate (Biswas and Narayanaswamy, 2006).

Fluorescein Di-acetate Hydrolysis (FDA) activity ( $\mu$ g fluorescein $\mathrm{g}^{-1}$ soil hour ${ }^{-1}$ )

Data in Table 1, shows significant variation in FDA activity $\left(8.35 \mu \mathrm{g}\right.$ fluorescein $\mathrm{g}^{-1}$ soil hour $^{-1}$ ) in the soil treated with $\mathrm{T}_{8}$ (enriched compost $5 \mathrm{t} \mathrm{ha}^{-1}$ ). FDA activity determines the live cells present in the soil

Arylsulphatase (ARS) and Arylesterase (ARE) activity ( $\mu$ g p-nitrophenol $\mathrm{g}^{-1}$ soil hour $^{-1}$ )

Similarly significant variation is observed in ARS activity $\left(20.79 \mu \mathrm{g}\right.$ p-nitrophenol $\mathrm{g}^{-1}$ soil hour $\left.^{-1}\right)$ and ARE activity $(147.97 \mu \mathrm{g}$ pnitrophenol $\mathrm{g}^{-1}$ soil hour $\left.{ }^{-1}\right)$. Arylsulphatase play a major role in the turnover and cycling of sulphur in soils by catalysing the hydrolysis of ester sulphates, and thus releasing organically bound sulphates into the soil solution Arylesterase activity is important for evaluating the response of soil microbial communities to organic contamination and remediation measures as it catalyses the hydrolysis of toxic metabolites and organophosphates and degradation of plastics. Addition of organic sources acts as a good source of carbon and energy to heterotrophs or microbes which keep them alive for a longer period of time. This is in conformity with Albiach et al., (2000) and Chang et al., (2007).

\section{Microbial population (log $\mathrm{cfu}^{-1}$ soil)}

It is clearly observed from the Table 1, that the highest microbial population of bacteria (7.11 $\log \mathrm{cfu} \mathrm{g}^{-1}$ soil) and fungal $4.16 \log \mathrm{cfu} \mathrm{g}^{-1}$ soil was recorded in $\mathrm{T}_{8}$ (Enriched compost $5 \mathrm{t} \mathrm{ha}^{-1}$ ). Sources of potential beneficial microbes in the enriched compost may possibly provide microbial diversity and activity of microorganisms accompanied by better $\mathrm{DH}$ and PMEase activity. Similar findings were also reported by Nath et al., 2012.

Manure application is known to stimulate and improve stable soil structure, fungal and bacterial population and biological activity (Chaoui et al., 2003).

\section{Effect of organics on soil physico-chemical properties}

\section{Soil pH ad organic carbon}

Data from Table 2 clearly indicates that there was a significant increase in soil $\mathrm{pH}$ (5.55) and organic carbon (1.12\%) when Enriched compost $5 \mathrm{t} \mathrm{ha}^{-1}\left(\mathrm{~T}_{8}\right)$ was applied to soil. Soil $\mathrm{pH}$ is a manifestation of $\mathrm{H}^{+}$and $\mathrm{OH}^{-}$activity by dissociation of water molecules. Higher $\mathrm{pH}$ in the organic treatments might be due to the deactivation of $\mathrm{Al}^{3+}$ and concomitant release of basic cations due to addition of organic matter (Gogoi, 2010). 
Table.1 Data of Microbial biomass carbon, dehudrogenase activity, phosphomonoesterase activity, fluorescein di-acetate activity, arylesterase activity, arylsulphate activity, bacteria and fungi

\begin{tabular}{|c|c|c|c|c|c|c|c|c|}
\hline Treatment & $\begin{array}{c}\text { Microbial } \\
\text { Biomass Carbon, } \\
\left(\mu \mathrm{g} \mathrm{g}^{-1} \text { soil } 24\right. \\
\left.\text { hour }^{-1}\right)\end{array}$ & $\begin{array}{l}\text { Dehydrogenase } \\
\text { activity } \\
\left(\mu \mathrm{g} \mathrm{TPF} \mathrm{g}^{-1} \text { soil }\right. \\
\left.24 \text { hour }^{-1}\right)\end{array}$ & $\begin{array}{l}\text { Phosphomonoest } \\
\text { erase activity } \\
(\mu \mathrm{g} \text { p-nitrophenol } \\
\left.\mathrm{g}^{-1} \text { soil hour }{ }^{-1}\right)\end{array}$ & $\begin{array}{l}\text { Fluorescein di- } \\
\text { acetate activity } \\
(\mu \mathrm{g} \text { fluorescein } \\
\left.\mathrm{g}^{-1} \text { soil hour }^{-1}\right)\end{array}$ & $\begin{array}{l}\text { Arylsulphatase } \\
\text { activity }(\mu \mathrm{g} \mathrm{p}- \\
\text { nitrophenol g }{ }^{-1} \\
\left.\text { soil hour }^{-1}\right)\end{array}$ & $\begin{array}{l}\text { Arylesterase } \\
\text { activity }(\mu \mathrm{g} \mathrm{p}- \\
\text { nitrophenol } \\
\left.\mathrm{g}^{-1} \text { soil hour }^{-1}\right)\end{array}$ & $\begin{array}{l}\text { Bacteria } \\
(\log \mathrm{cfu} \\
\left.\mathrm{g}^{-1} \text { soil }\right)\end{array}$ & $\begin{array}{l}\text { Fungi } \\
\text { (log cfu } \\
\mathrm{g}^{-1} \text { soil) }\end{array}$ \\
\hline $\begin{array}{l}\mathrm{T}_{1}: \text { RDF (20:20:20 } \mathrm{g} \mathrm{m}^{-2} \mathrm{NPK}+4 \\
\mathrm{~kg} \mathrm{~m} \mathrm{~m}^{-2} \text { FYM) }\end{array}$ & 262.00 & 92.40 & 40.66 & 4.70 & 13.29 & 126.50 & 5.32 & 3.28 \\
\hline $\mathrm{T}_{2}:$ Rock phosphate + Consortium & 237.55 & 90.92 & 37.18 & 5.15 & 14.60 & 127.64 & 5.25 & 3.23 \\
\hline $\mathrm{T}_{3}: \mathrm{T}_{2}+$ Vermicompost $\left(2.5 \mathrm{t} \mathrm{ha}^{-1}\right)$ & 449.94 & 106.63 & 44.78 & 6.13 & 18.34 & 134.09 & 6.05 & 3.44 \\
\hline $\mathrm{T}_{4}: \mathrm{T}_{2}+$ Vermicompost $\left(5 \mathrm{t} \mathrm{ha}^{-1}\right)$ & 500.90 & 112.76 & 51.36 & 6.29 & 18.47 & 142.78 & 6.22 & 3.47 \\
\hline $\mathrm{T}_{5}: \mathrm{T}_{2}+$ Compost $\left(2.5 \mathrm{t} \mathrm{ha}^{-1}\right)$ & 311.95 & 95.79 & 40.84 & 5.32 & 15.72 & 127.05 & 5.39 & 3.34 \\
\hline $\mathrm{T}_{6}: \mathrm{T}_{2}+\operatorname{Compost}\left(5 \mathrm{t} \mathrm{ha}^{-1}\right)$ & 364.72 & 99.27 & 42.91 & 5.62 & 16.42 & 131.67 & 5.45 & 3.38 \\
\hline $\mathrm{T}_{7}$ : Enriched Compost $\left(2.5 \mathrm{t} \mathrm{ha} \mathrm{C}^{-1}\right)$ & 500.10 & 115.38 & 51.97 & 7.28 & 18.31 & 140.60 & 6.23 & 3.72 \\
\hline $\mathbf{T}_{8}:$ Enriched Compost $\left(5 \mathrm{t} \mathrm{ha}{ }^{-1}\right)$ & 522.90 & 125.42 & 63.76 & 8.35 & 20.79 & 147.97 & 7.11 & 4.16 \\
\hline S.Ed $( \pm)$ & 3.86 & 2.83 & 1.01 & 0.33 & 0.48 & 1.81 & 0.37 & 0.10 \\
\hline $\mathrm{CD}(5 \%)$ & 8.27 & 6.07 & 2.17 & 0.71 & 1.02 & 3.88 & 0.79 & 0.22 \\
\hline
\end{tabular}

Table.2 Data of effect of organics on soil $\mathrm{pH}$, organic carbon, Available N, P and K

\begin{tabular}{|c|c|c|c|c|c|}
\hline Treatment & $\mathrm{pH}$ & $\begin{array}{c}\text { Organic Carbon } \\
(\%)\end{array}$ & $\begin{array}{c}\text { Available N } \\
\left(\mathrm{kg} \mathrm{ha}^{-1}\right)\end{array}$ & $\begin{array}{c}\text { Available P } \\
\left(\mathrm{kg} \mathrm{ha}^{-1}\right)\end{array}$ & $\begin{array}{c}\text { Available K (kg } \\
\left.\text { ha }^{-1}\right)\end{array}$ \\
\hline $\mathrm{T}_{1}: \operatorname{RDF}\left(20: 20: 20 \mathrm{~g} \mathrm{~m}^{-2} \mathrm{NPK}+4 \mathrm{~kg} \mathrm{~m}^{-2} \mathrm{FYM}\right)$ & 4.58 & 0.68 & 257.57 & 31.61 & 129.75 \\
\hline $\mathrm{T}_{2}:$ Rock phosphate + Consortium & 5.21 & 0.73 & 263.47 & 30.10 & 123.18 \\
\hline $\mathrm{T}_{3}: \mathrm{T}_{2}+$ Vermicompost $\left(2.5 \mathrm{tha}^{-1}\right)$ & 5.22 & 0.87 & 268.67 & 37.92 & 135.48 \\
\hline $\mathrm{T}_{4}: \mathrm{T}_{2}+$ Vermicompost $\left(5 \mathrm{tha}^{-1}\right)$ & 5.26 & 0.90 & 273.50 & 48.35 & 136.69 \\
\hline $\mathrm{T}_{5}: \mathrm{T}_{2}+$ Compost $\left(2.5 \mathrm{t} \mathrm{ha}^{-1}\right)$ & 5.11 & 0.76 & 264.76 & 34.62 & 127.62 \\
\hline $\mathrm{T}_{6}: \mathrm{T}_{2}+$ Compost $\left(5 \mathrm{t} \mathrm{ha}{ }^{-1}\right)$ & 5.19 & 0.78 & 269.67 & 36.08 & 128.67 \\
\hline $\mathrm{T}_{7}$ : Enriched Compost $\left(2.5 \mathrm{t} \mathrm{ha}^{-1}\right)$ & 5.25 & 0.88 & 272.30 & 45.04 & 135.23 \\
\hline $\mathrm{T}_{8}:$ Enriched Compost $\left(5 \mathrm{t} \mathrm{ha}^{-1}\right)$ & 5.55 & 1.12 & 282.62 & 54.94 & 143.22 \\
\hline S.Ed $( \pm)$ & 0.10 & 0.04 & 1.92 & 0.62 & 2.57 \\
\hline $\mathrm{CD}(5 \%)$ & 0.22 & 0.09 & 4.11 & 1.32 & 5.51 \\
\hline
\end{tabular}


Also, higher $\mathrm{pH}$ might be due to the increase in microbial activities in the root zone which decomposes organic manures and also fix unavailable form of mineral nutrient into available forms in soil thereby substantiates crop requirement and improve organic carbon level and stabilize soil $\mathrm{pH}$. Similar result was also reported by Tekasangla et al., (2015) in cauliflower. Organic carbon of soil acts as a sink and source of nutrients for microbial population, which regulates the availability of different nutrients through microbial transformation it is probably due to application of organic inputs and their releasing behaviour of different acids. However, before experimentation organic carbon and soil $\mathrm{pH}$ of $0.63 \%$ and 5.06 were found respectively.

\section{Available nitrogen, phosphorus and potassium}

Data presented in table 2, shows that there is significant variation in available nitrogen, phosphorus and potassium.

Available form of nitrogen is always in a state of dynamic change and hence its content in soil is highly variable. The highest available nitrogen of $282.62 \mathrm{~kg} \mathrm{ha}^{-1}$ were recorded under treatment $\mathrm{T}_{8}$ (Enriched compost $5 \mathrm{t}$ $\mathrm{ha}^{-1}$ ). Such a buildup of available $\mathrm{N}$ could be attributed to the availability of Rhizobium with Azotobacter to fix atmospheric $\mathrm{N}$ in the rhizosphere throughout the cropping period. Similar results have been reported by Workneh et al., (1993). Organically managed soil exhibited great of biological activity of inoculated microorganisms as well as their potential nitrogen fixation (Melero et al., 2006).

The highest available soil phosphorus status (54.94kg ha-1) was recorded in T8 (Enriched compost 5t ha-1). The increased available phosphorus might be attributed to the improvement of soil condition due to the application of compost and phosphate solubilising and mineralizing ability of the microorganisms from the soluble from of phosphorus sources (Tao et al., 2008). Microbial culture plays a vital role in the release of phosphorus sources due to production of phosphate solubilising enzymes. The minimum phosphorus content of soil $\left(30.10 \mathrm{~kg} \mathrm{ha}^{-1}\right)$ was recorded in consortium with rock phosphate inoculated treatment $\left(\mathrm{T}_{2}\right)$ which might be due to the lower rate of fixation of phosphorus during initial stage. These results were similar to the findings by Bahadur et al., 2006; Biswas (2008) and Umlong (2010).

In case of residual potassium, treatment $T_{8}$ receiving Enriched compost $5 \mathrm{t} \mathrm{ha}^{-1}$ showed higher potassium content of $143.22 \mathrm{~kg} \mathrm{ha}^{-1}$. This might be due to release of potassium from these organic amendments and also due to solubilisation of mineral based potassium or native potassium. The positive influence of organic manure on the available potassium was earlier reported by Srikanth et al., (2000).

\section{References}

Albiach, R., Canet, R., Pomares, F. And Ingelmo, F. (2000). Microbial biomass content and enzymatic activities after the application of organic amendments to a horticultural soil. Biores. Technol. 73: 43-48

Aldrich, J. and Baker, R. (1970). Biological control of Fusarium roseum f. sp. dianthi by Bacillus subtilis. Pl. Dis. Reporter, 54:446.

Bahadur, A., Singh, J., Singh, K.P., Upadhyay, A.K. and Rai, M. (2006). Effect of organic amendments and biofertilizers growth, yield and quality attributes of Chinese cabbage (Brassica pekinensis). Indian J. Agric. Sci. 76(10): 596-598 
Biswas, D. R. And Narayanasamy, G. (2006). Rock Phosphate Enriched Compost: An Approach to Low Grade Indian Rock Phosphate. Biores. Technol. 97: 22432251

Chang, E., Chung, R. And Tsai, Y. (2007). Effect of different application rates of organic fertilizer on soil enzyme activity and microbial population. Soil Sci. Pl. Nutri. 53(2): 132-140

Chaoui, H. I., Zibilske, L.M. and Ohno, T. (2003). Effects of earthworm casts and compost on soil microbial activity and plant nutrient availability. Soil Biol. Biochem. 35: 909-915.

Gogoi, B., Barua, N. G. and Barua, T. C. (2010). Effect of integrated supply of nutrient on soil microbial biomass carbon in an inceptisol of Assam. $J$. Indian Soc. Soil Sci. 58(2): 241-244.

Melero, S., Porros, J. D., Herencia, J.F. and Madegon, E. (2006). Chemical and biochemical properties in a silty loam soil under conventional and organic management. Soil Tillage Res. 90:162170

Nath, D. J., Ozah, B., Baruah, R., Barooah, R. C., Borah, D. K. and Gupta, M. (2012). Soil enzymes and microbial biomass carbon under Rice-Toria sequence as influenced by nutrient management. $J$. of Ind. Soc. of Soil Sci. 60: 20-24.

Rajkonwar, U. (2012). Assessment of organic sources on microbial biomass and nutrient availability in tea soil. M.Sc. (Agri.) Thesis. Assam Agricultural University, Jorhat.
Rao, D. L. N. (2007). Microbial Diversity, Soil Health and Sustainability. J. Ind. Soc. Soil Sc. 55:392-403

Singh, R., Kumar, M., Raj, S. Kumar, S. (2014). Flowering and corm production in gladiolus (Gladiolus grandiflorus L.) cv. "White Prosperity" as influenced by Integrated Nutrient Management (INM). Ann. Hort. 7(1): 36-42

Srikanth, K., Srinivasamurthy, C. A., Siddaramappa, R. $\quad$ and Ramaurishnaparama, V. R. (2000). Direct and residual effect of enriched composts, FYM, vermicompost and fertilizers on properties of an Alfisol. $J$. Ind. Soc. Soil Sci. 48: 496-499.

Subhani, A., Changyong, H; Zhengmiao, Y., Min, L. and EL-ghamry, A. (2001): Impact of soil environment and agronomic practices on microbial dehydrogenase enzyme activity in soilA Review. Pak. J. Biol. Sci. 4: 333-338

Tekasangla; Kanaujia, S.P. and Singh, P.K. (2015). Integrated nutrient management for quality production of cauliflower in acid alfisol of Nagaland. Karnataka J. Agril. Sci. 28(2): 244-247

Umlong, R.M. (2010). Growth, yield and quality of carrot (Daucas carota L.) as influenced by organics and lime. M.Sc. (Agri.) Thesis, Assam Agricultural University, Jorhat.

Workneh, F., Bruggen, A. H. C., Drinkwater, L. E. and Shennan, C. (1993). Variables associated with corky root and phytopthora rot of tomatoes in organic and conventional farms. Phytopathol. 83: 581-589.

\section{How to cite this article:}

Dipanjali Baruati, Madhumita Choudhury Talukdar, Dhrubajyoti Nath and Tara Bhuyan. 2018. Effect of Organic Input Application on Soil Microbial and Biochemical Properties on Gladiolus (Gladiolus grandiflorus L.) under Jorhat Condition. Int.J.Curr.Microbiol.App.Sci. 7(10): 14771482. doi: https://doi.org/10.20546/ijcmas.2018.710.165 